\title{
Suitability of Silica Gel To Process INEEL Sodium Bearing Waste
}

R. J. Kirkham

A. K. Herbst

September 2000

Idaho National Engineering and Environmental Laboratory Bechtel BWXT Idaho, LLC 


\title{
Suitability of Silica Gel to Process INEEL Sodium Bearing Waste
}

\author{
R. J. Kirkham \\ A. K. Herbst
}

September 2000

\section{Idaho National Engineering and Environmental Laboratory Idaho Falls, Idaho 83415}

Prepared for the

U.S. Department of Energy

Assistant Secretary for Environmental Management Under DOE Idaho Operations Office

Contract DE-AC07-99ID13727 


\section{INTRODUCTION}

The suitability of using the silica gel process for Idaho National Engineering and Environmental Laboratory (INEEL) sodium bearing waste was investigated during fiscal year 2000. The study was co-funded by the Tanks Focus Area as part of TTP No. ID-77WT-31 and the High Level Waste Program. The task also included the investigation of possible other absorbents. Scoping tests and examination of past work showed that the silica gel absorption/adsorption and drying method was the most promising; thus only silica gel was studied and not other absorbents.. The documentation on the Russian silica gel process provided much of the needed information but did not provide some of the processing detail so these facts had to be inferred or gleaned from the literature ${ }^{1,2}$.

The Russian process is designed to sorb solutions into silica gel; then, drive out the water and any acids that may form by heating to a temperature near $120^{\circ} \mathrm{C}$. This treatment results in a dry flowing intermediate product that is suitable for storage. The intermediate product can be calcined at high temperatures for a permanent waste form or the metals can be recovered from the gel by leaching with nitric acid. The intermediate product can be converted into a glass or cement waste forms.

The silica-sol gel technology is an alternative for the treatment of INEEL liquid waste forms. It employs adsorption/absorption, chemical reaction and evaporation for the first step. Per review of the literature ${ }^{1,2}$ and further evaluation of the chemistry, it appeared feasible to denitrate at least a fraction of the INEEL sodium bearing waste by vaporizing nitric acid at a reasonably low temperature. Further denitration also appeared possible without the addition of reductant materials. Processing may be feasible on the other projected INEEL low activity liquid waste streams.

Information from the literature ${ }^{3,4}$ indicates that metal ions, especially iron and aluminum, will react with silica gel releasing hydrogen ion:

$$
\mathrm{M}^{\mathrm{n}+}+\mathrm{m}(\mathrm{OSi}-)=\mathrm{M}(\mathrm{OSi}-)_{\mathrm{m}}^{\mathrm{n}-\mathrm{m}}+\mathrm{mH}^{+} \quad \text { Eq. } 1 .
$$

The reaction is reversible in acidic solutions. As the temperature and the concentration is increased during evaporation, the equilibrium is forced to the right. Formed volatile acids are then evaporated off. This releases some of the nitrate as nitric acid, and as indicated in our experimental work, the entire nitrate associated with iron and most of that with aluminum is released at temperatures less than $130^{\circ} \mathrm{C}$. 


\section{TEST WORK SUMMARY}

Tests were conducted using concentrated sodium bearing waste simulant and Grade 12 silica gel to further evaluate the process. The results of these tests are summarized as follows:

1. Product waste loadings to $84 \mathrm{wt} \%$ of the total gel plus simulant mass was dry and flowable when treated at $110^{\circ} \mathrm{C}$.

2. Volume reduction of over $30 \%$ based on the volume of simulant feed was demonstrated.

3. Up to $46 \%$ denitration of the simulant was possible without visible $\mathrm{NO}_{\mathrm{x}}$ production at a temperature up to $132^{\circ} \mathrm{C}$. This indicates that most of the aluminum and iron no longer have nitrate associated and are present in the dried product as different species. The acid concentration of the collected condensate was about 3.5 molar.

4. Leach solutions from the heat treated product produced between 120 and $140^{\circ} \mathrm{C}$ have measured $\mathrm{pH}$ values between 4 and 6 , indicating near complete acid vaporization. When the product was heated to over $400^{\circ} \mathrm{C}$, the $\mathrm{pH}$ of the leach solution was over 10 and most of the sodium was denitrated.

5. Temperatures above $135^{\circ} \mathrm{C}$ produced visible $\mathrm{NO}_{\mathrm{x}}$.

6. Without subsequent treatment, between 50 and $80 \mathrm{wt} \%$ of the calculated dried/absorbed simulant was water leachable. At treatment temperatures above $400^{\circ} \mathrm{C}$, the leachability begins to decrease. At $600^{\circ} \mathrm{C}$ and $81 \mathrm{wt} \%$ loading, the water leachable fraction was reduced to about $5 \mathrm{wt} \%$.

7. The dry gel product can be stored until needed then retrieved for further processing into a glass or cement waste form. Loaded dry gel product is easily made into a glass. It can be fed dry to a melter without concern about hot acid vapors in the offgas. All three test glasses made from the SBW product passed the PCT test. The glasses appeared to be free from crystallization and the $80 \mathrm{wt} \%$ loaded gel produced a glass with an overall simulant to glass volume reduction ratio of near 10 .

8. The TCLP leaching failed on all the non-glass products tested. Chromium, cadmium, and lead leached from the dry gel product. Mercury was not detected in the leach solutions. 


\section{EXPERIMENTAL}

\section{Initial Testing}

Scoping tests were performed to determine the maximum desirable waste loading. The waste simulant used was from the concentrated sodium bearing waste flowsheet dated 12/9/98. The constituents used to makeup the simulant are shown as Table 1. Two types of gel were used: one a course grade 12 and the other a chromographic grade silicic acid of 240 mesh.

Table 1. Concentrated Sodium Bearing Waste Simulant Composition (gmol/L).

\begin{tabular}{|c|c|c|}
\hline Species & $\begin{array}{c}\text { SBW- } \\
\text { LAW } \\
\text { Average }\end{array}$ & $\begin{array}{l}\text { Stock Chemicals Used for } \\
\text { Mixing the Simulants }\end{array}$ \\
\hline Acidity & 1.94 & $\mathrm{HNO}_{3}, \mathrm{HBF}_{4}$, etc \\
\hline $\mathrm{Al}$ & 0.784 & $\mathrm{Al}\left(\mathrm{NO}_{3}\right)_{3}$ sol'n \\
\hline $\mathrm{B}$ & 0.0191 & $\mathrm{HBF}_{4} 50 \%$ solution \\
\hline $\mathrm{Ba}$ & $7.23 \mathrm{E}-5$ & $\mathrm{Ba}\left(\mathrm{NO}_{3}\right)_{2}$ \\
\hline $\mathrm{Ca}$ & 0.0576 & $\mathrm{CaO}$ \\
\hline $\mathrm{Cd}$ & 0.0001 & $\mathrm{Cd}\left(\mathrm{NO}_{3}\right)_{2} \bullet 4 \mathrm{H}_{2} \mathrm{O}$ \\
\hline $\mathrm{Cl}$ & 0.0405 & $\mathrm{HCl}$ \\
\hline $\mathrm{Cr}$ & $0.0001^{1}$ & $\mathrm{Cr}\left(\mathrm{NO}_{3}\right)_{3} \cdot 9 \mathrm{H}_{2} \mathrm{O}$ \\
\hline Cs & $2.76 \mathrm{E}-5$ & $\mathrm{CsNO}_{3} \&{ }^{137} \mathrm{CsCl}$ \\
\hline $\mathrm{F}$ & 0.0712 & $\mathrm{HF}, \mathrm{ZrF}_{4}, \mathrm{HBF}_{4}$ \\
\hline $\mathrm{Fe}$ & 0.0271 & $\mathrm{Fe}\left(\mathrm{NO}_{3}\right)_{3} \cdot 9 \mathrm{H}_{2} \mathrm{O}$ \\
\hline $\mathrm{Hg}$ & $0.0001^{1}$ & $\mathrm{Hg}\left(\mathrm{NO}_{3}\right)_{2} \bullet \mathrm{H}_{2} \mathrm{O}$ \\
\hline $\mathrm{K}$ & 0.245 & $\mathrm{KNO}_{3}$ \\
\hline $\mathrm{Mg}$ & -- & $\mathrm{MgO}$ \\
\hline $\mathrm{Mn}$ & 0.0159 & $\mathrm{Mn}\left(\mathrm{NO}_{3}\right)_{2}$ sol'n \\
\hline Mo & 0.000843 & $\mathrm{MoO} 3$ \\
\hline $\mathrm{Na}$ & 2.36 & $\mathrm{NaNO}_{3}$ \\
\hline $\mathrm{Ni}$ & 0.00227 & $\mathrm{Ni}\left(\mathrm{NO}_{3}\right)_{2} \cdot 6 \mathrm{H}_{2} \mathrm{O}$ \\
\hline $\mathrm{NO}_{3}$ & 6.95 & $\begin{array}{c}\mathrm{HNO}_{3,} \mathrm{Ca}\left(\mathrm{NO}_{3}\right)_{2}, \mathrm{NaNO}_{3}, \\
\text { etc }\end{array}$ \\
\hline $\mathrm{Pb}$ & $0.0001^{1}$ & $\mathrm{~Pb}\left(\mathrm{NO}_{3}\right)_{2}$ \\
\hline $\mathrm{PO}_{4}^{-3}$ & 0.0204 & $\mathrm{H}_{3} \mathrm{PO}_{4}$ \\
\hline $\mathrm{Sr}$ & $2.04 \mathrm{E}-5$ & $\mathrm{Sr}\left(\mathrm{NO}_{3}\right)_{2}$ \\
\hline $\mathrm{SO}_{4}^{-2}$ & 0.0637 & $\mathrm{H}_{2} \mathrm{SO}_{4}$ \\
\hline $\mathrm{TcO}_{4}^{-}$ & $1.17 \mathrm{E}-5$ & $\mathrm{NH}_{4} \mathrm{TcO}_{4}$ \\
\hline $\mathrm{ZrOF}^{-}$ & 0.00731 & $\mathrm{ZrF}_{4}$ \\
\hline
\end{tabular}

An initial test was conducted using the silicic acid. The mixture was allowed to dry over the weekend at ambient temperature and became free flowing with yellow coloration and some crustiness. This product was then placed in an oven overnight at $115^{\circ} \mathrm{C}$ and the indicated weight loss of dried simulant was over $82 \%$. The sample was leached with demineralized water and the 
centrifuged solution evaporated. The dried solids from the solution indicated a leachability of just less than $80 \mathrm{wt} \%$ for the sample. To determine the species that leached out, the dried leachates were submitted for XRD and a SEM semi-quant. analysis. Sodium nitrate appeared as the major crystalline form with some potassium nitrate. In the SEM, sodium appeared with the large crystals with the potassium deposited on the edges. A small amount of aluminum was also present.

For the subsequent comparison test, both types of gel were used and performance was about the same. The gel amounts were weighed out and the simulant was added for waste loadings of 60 , 70,80 and 85 weight percent. When mixed, all but the $60 \%$ loaded samples had free liquid above the gel volume. The $60 \%$ loaded samples had the consistency of wet sand. The beakers containing the mixtures were placed in an oven set at $100^{\circ} \mathrm{C}$ for four hours and removed for weighing. The liquid was essentially gone for the 60 and $70 \%$ loaded gels with minor crusting forming on the $70 \%$ sample. The other two loadings still had standing liquid. All eight were stirred and returned to the oven set at $120^{\circ} \mathrm{C}$. This process was repeated once more to the temperature of $140^{\circ} \mathrm{C}$. The results are shown in Table 2 .

Table 2, Percent of Indicated Simulant Mass Remaining After

\begin{tabular}{|l|c|c|c|c|}
\hline \multicolumn{5}{|c|}{ Evaporation at Temperature } \\
\hline Sample & $\begin{array}{c}\text { Actual } \\
\text { Loading } \\
\%\end{array}$ & $100^{\circ} \mathrm{C}$ & $120^{\circ} \mathrm{C}$ & $140^{\circ} \mathrm{C}$ \\
\hline $60-1$ & 57.1 & 24.7 & 17.1 & 15.7 \\
\hline $70-1$ & 69.9 & 56.5 & 20.2 & 19.5 \\
\hline $80-1$ & 82.1 & 60.0 & 23.3 & 22.1 \\
\hline $90-1$ & 85.2 & 61.1 & 33.6 & 22.1 \\
\hline & & & & \\
\hline $60-2$ & 59.8 & 35.1 & 22.1 & 20.8 \\
\hline $70-2$ & 72.5 & 48.7 & 20.1 & 19.3 \\
\hline $80-2$ & 80.1 & 57.9 & 23.5 & 22.7 \\
\hline $90-2$ & 85.0 & 58.2 & 28.3 & 23.6 \\
\hline
\end{tabular}

From Table 2, it is apparent that for all the waste loadings tested, more than $75 \%$ of the mass can be removed at $140^{\circ} \mathrm{C}$. Most of this is water and nitric acid. The heavy crusting formed on the samples loaded above $80 \mathrm{wt} \%$ rendered them non-flowing mixtures. Subsequent results have shown that the product is flowable with waste loadings up to $84 \mathrm{wt} \%$. The grade 12 silica gel was chosen for subsequent testing because of better handling characteristics and because the silicic acid did not present a more noticeable advantage. This was the same conclusion reached in prior work ${ }^{2}$.

The weight loss of silica gel on heating alone was determined so that the accuracy of the simulant loss values could be determined. Losses varied from $0.99 \%$ at $100^{\circ} \mathrm{C}$ to $1.9 \%$ at $140^{\circ} \mathrm{C}$. A Grade 12 gel sample taken to $850^{\circ} \mathrm{C}$ for seven hours showed a weight loss of $2.34 \%$. 
An XRD on the unheated gel showed only amorphous material. This indicates that the raw gel material contains very little other than $\mathrm{SiO}_{2}$.

\section{Loading Tests}

From the work above, it appeared that the loading could be increased above $70 \mathrm{wt} \%$ and still avoid the crusting if the simulant were added incrementally to the gel. Enough simulant was added to the silica gel to approximate a waste loading of 50\%. Smaller amounts were added after partial evaporation had occurred until the loading was about $75 \%$ (actual $72.3 \mathrm{wt} \%$ ). After the final addition, the sample was placed in the oven at $120^{\circ} \mathrm{C}$ for the weekend. The results of this experiment, the iterative addition experiment, were not entirely satisfactory because there was minor crusting. Most of the crusting was avoided in later test work by more frequent stirring. Continuous stirring of the mixture at temperatures near $110^{\circ} \mathrm{C}$ eliminated the crusting while allowing for waste loadings above $80 \mathrm{wt} \%$.

Looking at the SEM pictures of the particles, Figures 1 and 2, two things are apparent: there are smaller particles throughout the solids of the loaded gel, Figure 2, and the average size of the larger particles is smaller than in the unloaded gel, Figure 1.

Figure 1, Grade 12 silica gel

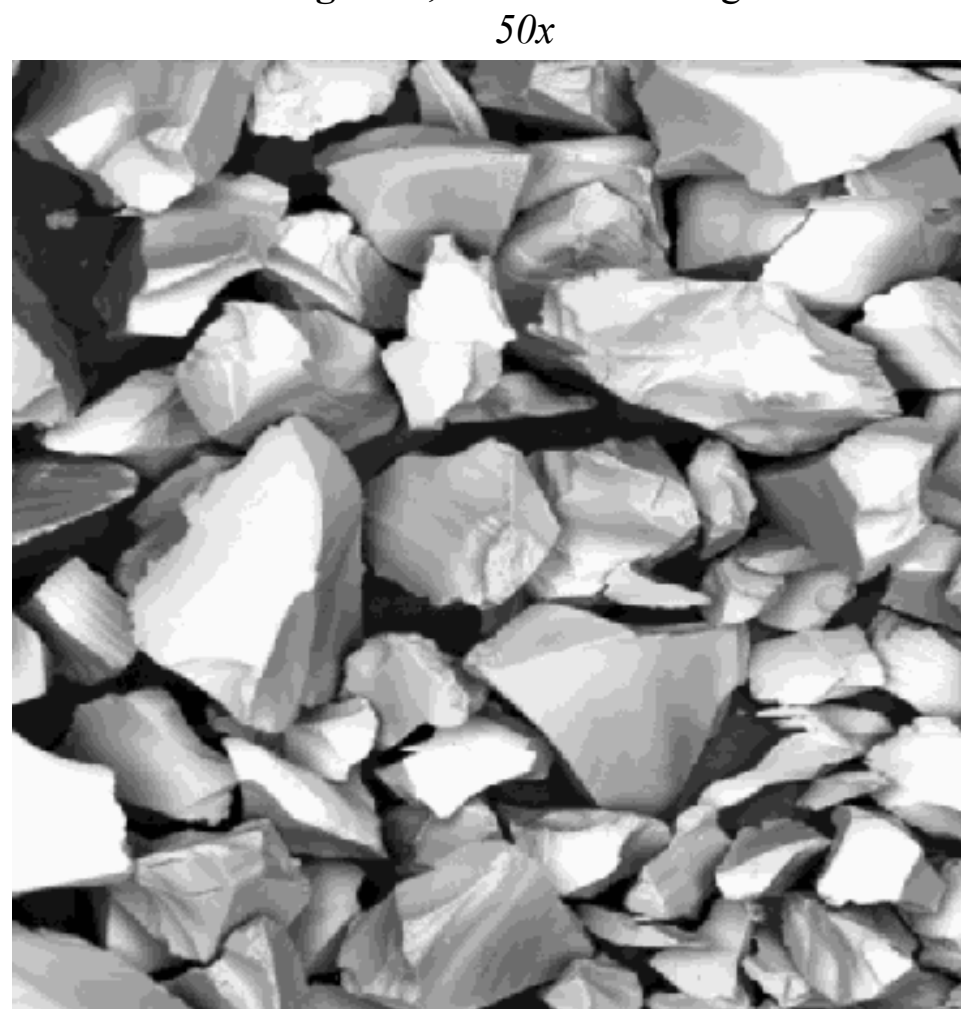

Apparently the silica gel spalled off small chunks during the process of alternate evaporation and cycling of temperature. The SEM semi-quantitative analysis results, shown in Table 3, indicate the smaller size fraction to be enriched in $\mathrm{Na}$ and relatively depleted in $\mathrm{Si}$ and Al. An XRD analysis showed mainly amorphous material with sodium nitrate as the major crystalline component with an unidentified major. The great difference in $\mathrm{Na}$ in the overall analysis tends to 
indicate surface precipitation in the iterative experiment. SEM analyses determine only surface values and will not indicate the absorbed chemicals. Also shown in Table 3 is the semiquantitative analysis of Run 3, which had a waste loading of $60 \mathrm{wt} \%$.

Figure 2, Loaded Grade 12 silica gel-72.3 wt\% $50 x$

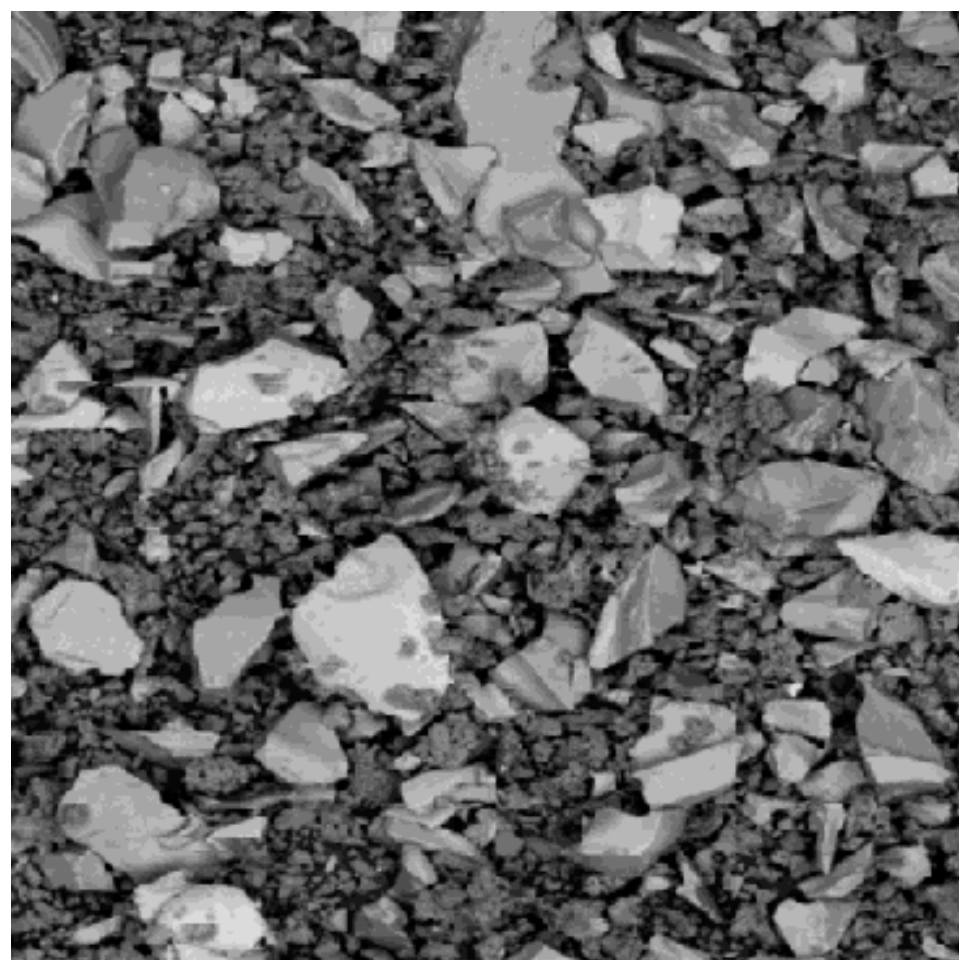

Table 3, Scanning Electon Microscope (SEM) Semi-Quant.

\begin{tabular}{|l|c|c|c|c|c|}
\hline \multicolumn{1}{|c|}{ Element At \% } & $\mathrm{Na}$ & $\mathrm{Al}$ & $\mathrm{Si}$ & $\mathrm{S}$ & $\mathrm{K}$ \\
\hline Figure 2 & & & & & \\
\hline Both Phases & 10.92 & 3.88 & 21.74 & 0.49 & 0.84 \\
\hline Small Particles & 31.86 & 3.56 & 7.71 & 0.82 & 0.66 \\
\hline Large Particles & 2.79 & 4.2 & 27.02 & 0.4 & 0.84 \\
\hline Figure 3 & & & & & \\
\hline R-3 All & 4.24 & 1.96 & 28.59 & 0.06 & 0.42 \\
\hline
\end{tabular}

The iterative test sample was screened with the separation at 150 microns. Mass fraction retained by the larger particle fraction was $68.5 \%$. Both fractions were leached in demineralized water, centrifuged, rinsed, centrifuged again, and then placed over a weekend in the oven other at $132^{\circ} \mathrm{C}$. The leachable fraction of smaller size particles was $26.3 \mathrm{wt} \%$ and contained $15.5 \%$ of total gel product mass. The leachable fraction of the larger particles contained $10.8 \%$ of the total 
gel product mass. It may be that the gel became saturated or the pores became choked off during the process such that the simulant added later had to evaporate on the surfaces. The smaller particles also provided more area and greater overall surface tension to get the liquid to adhere. A summary of this and other results are presented in Table 4 with the results of the mass balance experiments.

\section{Mass Balance Runs}

A series of five experiments were conducted to obtain information about the vapor emitted and provide a mass balance. A flask located inside a convection oven was connected through the oven wall to a condenser, followed by a condensate collection vessel and Drierite column. The first two runs did not have a purge gas and they did not reach the evaporative loss of mass indicated by the prior experiments. A loss as percentage of starting simulant was 61 to $63 \mathrm{wt} \%$ as opposed to $75 \mathrm{wt} \%$ on the iterative addition test above and about $80 \mathrm{wt} \%$ on some of the earlier scoping tests. These lower values resulted despite leaving the system running at temperature overnight. It was believed that the system contained a large closed volume and because the earlier tests were conducted in open containers with natural convection, that a purge was necessary. Normal mass diffusion may have been too slow. Due to the lack of evaporation in the earlier tests, Run 3 was operated with a purge line connected to the heated flask. An air purge rate of about $900 \mathrm{ml} / \mathrm{hr}$ was used. This resulted in an evaporative loss of $78.7 \mathrm{wt} \%$ as a percentage of starting simulant. A SEM picture of the Run 3 product is shown as Figure 3. It can be noted that there are very few of the smaller particles observed in the picture from the iterative experiment. Screening of the Run 3 product showed an $8.9 \mathrm{wt} \%$ fraction below 150 microns. A factor of three less than the iterative experiment product. This value is about half the highest value for the original gel, $16.8 \mathrm{wt} \%$.

Figure 3, Loaded Grade 12 Silica Gel-Run 3 Product- 60.1 wt $\%$

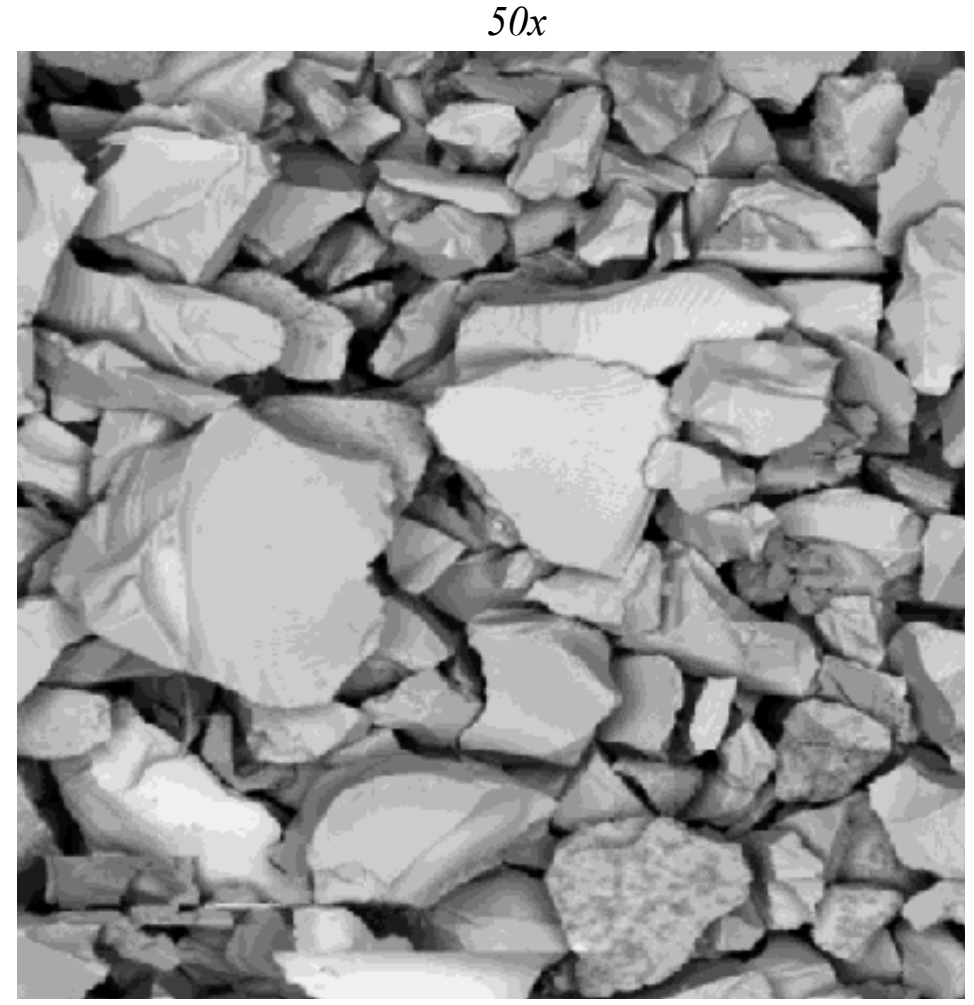


The Russian Gupka was tested with sodium bearing waste. The material is mostly $\mathrm{SiO}_{2}$ and was supplied as a cylinder of modified sintered coal fired fly ash. A Gupka run was set up in a like manner to Run 3 with periodic additions of raw concentrated simulant to the cylinder after some interim evaporation. As more and more simulant was added to the surface of the cylinder, the void space between the particles began to seal off. Eventually no more simulant would absorb. It was apparent that there was more void space within the cylinder and information that was available indicated such. Some surface reaction of the simulant with Gupka material had sealed the pathways to the interior. Even so, the waste loading was nearly $70 \mathrm{wt} \%$. It has been surmised but not verified that the small amount of fluoride in the SBW attacked the silica during the evaporative concentration. There were also indications the temperature could have an effect. The results of the measured parameters of the Gupka experiment are summarized with the other runs in Table 4.

\section{TABLE 4, Comparison of Silica Gel Experiments and Gupka Material with Sodium Bearing Waste} Simulant

\begin{tabular}{|c|c|c|c|c|c|c|c|c|}
\hline $\begin{array}{l}\text { Parameter } \backslash \\
\text { Experiment }\end{array}$ & $\begin{array}{l}\text { Scoping Test } \\
70-2\end{array}$ & $\begin{array}{c}\text { Iterative } \\
\text { Addition Test }\end{array}$ & Run 1 & Run 2 & Run 3 & Gupka & $\begin{array}{l}\text { Run } 4 \\
\text { (iterative ) }\end{array}$ & $\begin{array}{l}\text { 84H Max } \\
\text { Load }\end{array}$ \\
\hline $\begin{array}{l}\text { Waste Loading-Simulant \% of } \\
\text { Total Mass }\end{array}$ & 72.5 & 73.2 & 66.5 & 50.1 & 60.1 & 69.3 & 80.1 & 84.24 \\
\hline $\begin{array}{c}\text { Calculated wt } \% \text { of Simulant } \\
\text { left @120 } 120^{\circ}\end{array}$ & 23.5 & 24.6 & 58.2 & NA & 28.8 & NA & NA & 42.9 \\
\hline $\begin{array}{c}\text { Calculated wt } \% \text { of Simulant } \\
\text { left @132 } \mathrm{C}\end{array}$ & NA 19.3@140 & NA & 38.2 & 37.31 & 21.33 & 24.27 & 26.3 & NA \\
\hline $\begin{array}{c}\text { Accountability Mass Balance } \\
\%\end{array}$ & NA & NA & 99.21 & 95.2 & 98.6 & 98.3 & 99 & NA \\
\hline Sp. Gr. of Final Condensate & NA & NA & 1.0798 & 1.067 & 1.113 & 1.111 & 1.119 & NA \\
\hline $\begin{array}{c}\text { Concentration of Acid in } \\
\text { condensate } \underline{M}\end{array}$ & NA & NA & 2.42 & 2.03 & 3.75 & 3.6 & 3.57 & NA \\
\hline $\begin{array}{c}\text { Calculated Denitration Based } \\
\text { on HNO3 in Condensate } \%\end{array}$ & NA & NA & 25.61 & 18.92 & 45.92 & 50.2 & 43.4 & NA \\
\hline Bulk Density of Product $\mathrm{g} / \mathrm{cm} 3$ & 0.882 & 0.914 & 0.829 & 0.702 & 0.844 & 0.606 & 1.002 & 1.008 \\
\hline $\begin{array}{l}\text { Volume Change based on } \\
\text { Starting Simulant }+/-\%\end{array}$ & -10.10 & -10.10 & 40.60 & 157.00 & 37.00 & 47.9 & -32.6 & -44.1 \\
\hline $\begin{array}{c}\text { Swelling Based on Starting } \\
\text { Gel Volume \% }\end{array}$ & 129.00 & 132.00 & 156.00 & 145.00 & 116.00 & NA & 148 & 168 \\
\hline $\begin{array}{l}\text { Water Leachability- As \% of } \\
\text { calculated dried simulant }\end{array}$ & NA & 63.84 & 57.49 & NA & 51.32 & NA & 62.34 & NA \\
\hline $\begin{array}{l}\text { Calc. Fraction of Dry Solids } \\
\text { Loaded as Oxides in Product }\end{array}$ & 0.21 & 0.21 & 0.17 & 0.09 & 0.13 & 0.18 & 0.29 & 0.35 \\
\hline
\end{tabular}

An iterative run, Run 4, was used to demonstrate production of a good product with a volume reduction of $32.8 \%$ of the original simulant. The increments of simulant were added and mixed while the gel and the vessel were still hot. The losses of material were less than expected with a 99\% mass accountability. The final bulk density was over one. Run 4 product was used for further testing, including one of the glasses.

Heavy metals were added to the simulant and product was made for leach studies. A maximum loading was determined by using the same iterative addition as above. A waste loading of over $85 \mathrm{wt} \%$ was produced but the product was very crusty. Two other products were made from the hazardous simulant, one at $84.2 \mathrm{wt} \%$ and one at $80.9 \mathrm{wt} \%$. These were designated $84 \mathrm{H}$ and $81 \mathrm{H}$ respectfully. The properties of product $84 \mathrm{H}$ are shown in Table 4 . It was discovered that 
operating the oven at a lower temperature, 105 to $110^{\circ} \mathrm{C}$, allowed the gel to be iteratively loaded much more easily and with less crusting than prior tests. Two other non-hazardous products were made in bulk in open beakers, and designated 70-105 and 75-105. The product from Run 4 was also used in the leach studies and was designated 80-132.

\section{Leach Studies}

Products made at lower temperature have been known to leach readily. Past work ${ }^{1,2}$ reported that leachability decreased with temperature. Five products were heat treated overnight at progressively higher temperatures, then leached. The leaching was for a minimum of 20 hours at which time the solids and leachate was separated by centrifugation and the solids washed. The wash solution was separated in like manner and added to the leachate. The solids were then dried overnight at $130^{\circ} \mathrm{C}$ and the weights recorded. Leachates were analyzed for nitrate and $\mathrm{pH}$. Data resulting from these studies is presented in Figures 5 through 7.

\section{Figure 5, Leachability of Heat Treated Product}

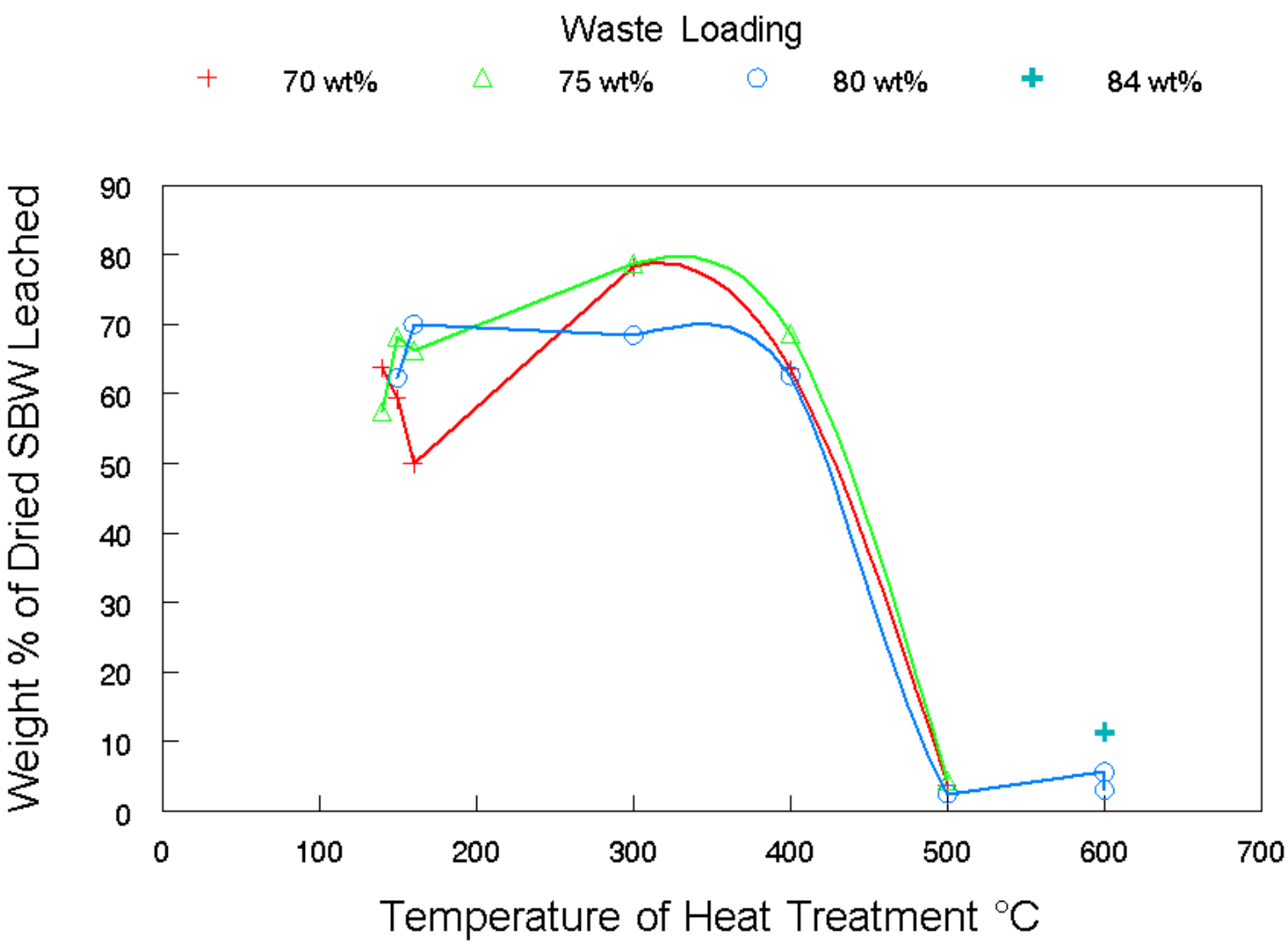

The amount of dried simulant leached from the product at the different loadings and temperature treatments using ambient temperature water is shown in Figure 5. The leachability increases from $160^{\circ}$ to $300^{\circ} \mathrm{C}$ then decreases to $400^{\circ} \mathrm{C}$ and drops off at $500^{\circ} \mathrm{C}$. The pattern is fairly consistent. At temperatures near $300^{\circ} \mathrm{C}$ the alkali metal nitrates lose all water and between 307 and $334^{\circ} \mathrm{C}$ the anhydrous forms are liquid. What nitrates may have been "locked in the gel 
matrix" are then more mobile. The leachability is about the same after treatment at $400^{\circ} \mathrm{C}$ as it was at about $150^{\circ} \mathrm{C}$. Apparently at $500^{\circ} \mathrm{C}$ the pores within the gel are closing off.

The $\mathrm{pH}$ of the leachates are above 10 after $400^{\circ} \mathrm{C}$ as shown in Figure 6 . There may be some alkaline attack on the gel because of obvious denitration. The attack may help in sealing off the gel pores.

\section{Figure 6, Leachate $\mathrm{pH}$ vs Temperature of Treatment}

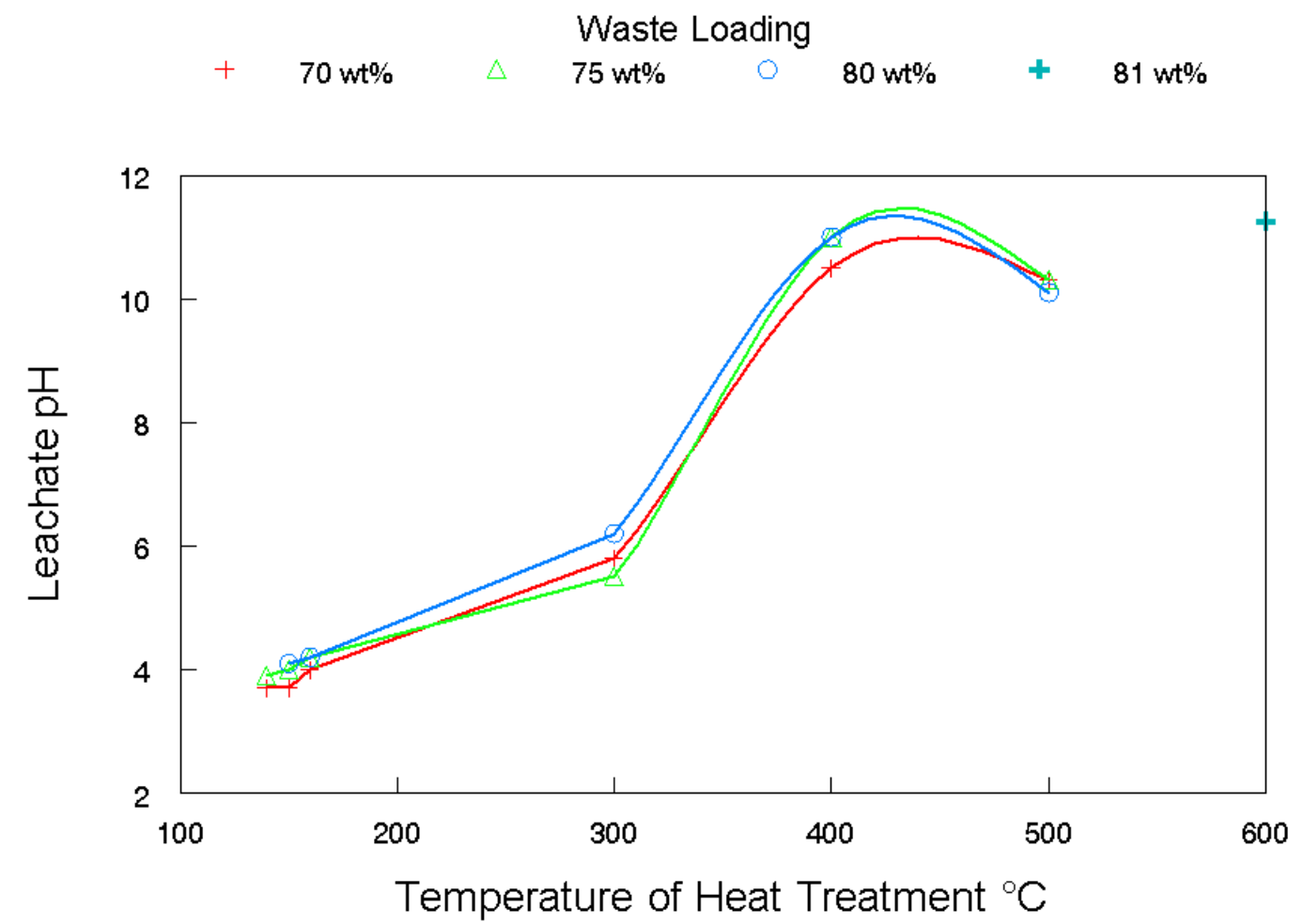

A plot of leachate $\mathrm{pH}$ with temperature is shown in Figure 6. There is a steady increase of value with temperature treatment. With a loss of acidity after $300^{\circ} \mathrm{C}$, the leachates become alkaline. It is not presently known why there is a dip in $\mathrm{pH}$ at the $500^{\circ} \mathrm{C}$ leachate. It may be that the freed $\mathrm{Na}_{2} \mathrm{O}$ is reacting with the silica. The results are consistent across waste loadings. The amount of nitrate in the leachates as a fraction of dried simulant was about the same at all temperature treatments up to $500^{\circ} \mathrm{C}$ (Figure 6). There was variability but no obvious trends. This indicates that there was not a complete denitration at $500^{\circ} \mathrm{C}$.

To keep track of dried simulant to product fraction, weights were taken before and after the product heat treatment. A summary of the dried simulant weight decrease versus temperature is presented as Figure 7. The fraction of the original simulant mass is plotted with temperature. There is no plateau of loss with temperature and product 70-105 has decreased to about 0.12. Calculated values for the simulant components as oxides are about 0.10 weight fraction remaining, thus, product $70-105$ was nearly denitrated at $500^{\circ} \mathrm{C}$. 


\section{Figure 7, Retained Weight Fraction of Simulant}

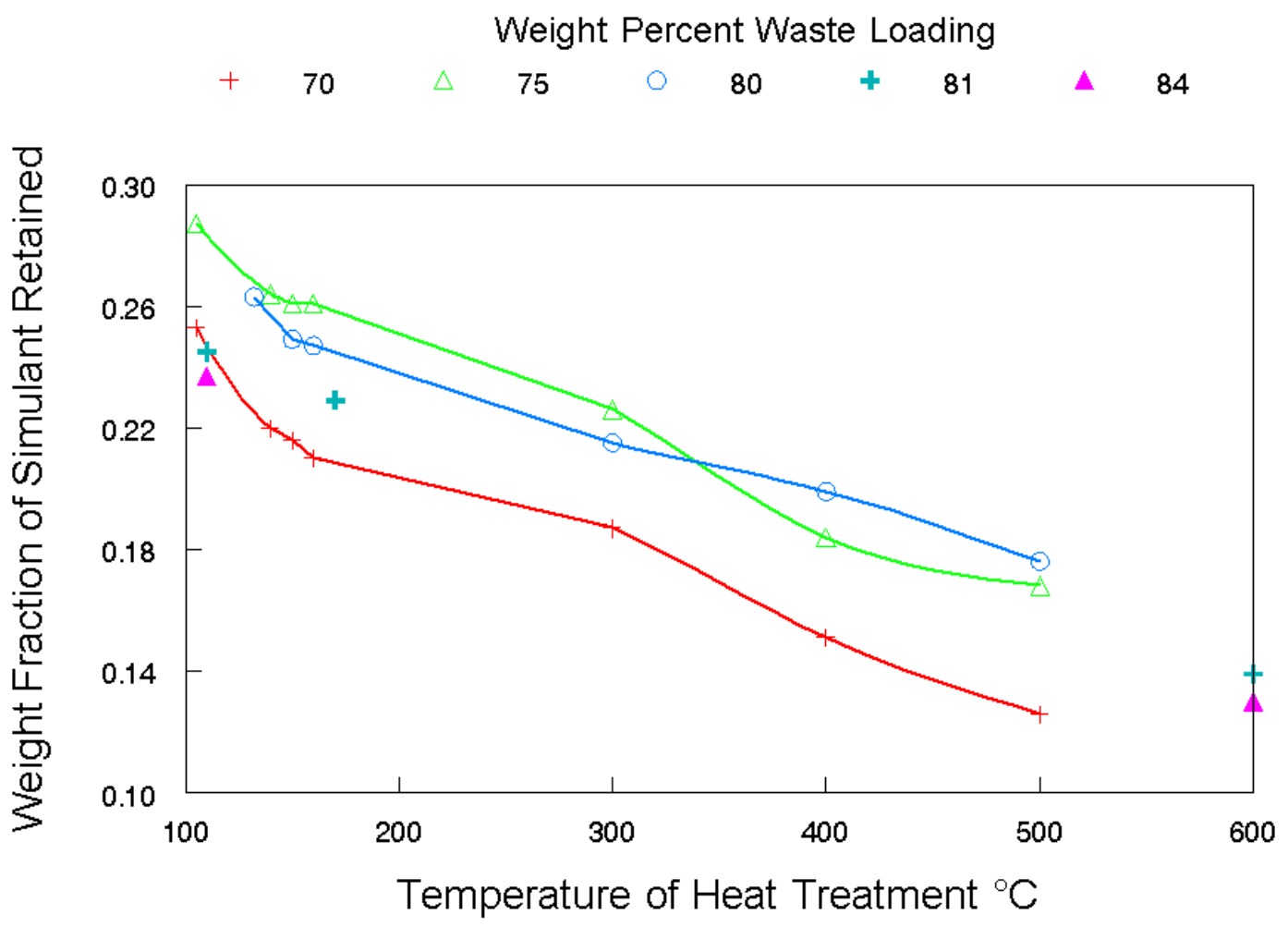

The $81 \mathrm{H}$ product was prepared for TCLP by heating to $170^{\circ} \mathrm{C}$ to drive off more of the acid while still leaving some bound water. Sodium sulfide was added in double the stoichiometric amount to reduce and react with the heavy metals and mixed in just enough water to make the loaded gel moist. The gel immediately turned black. After about 3 minutes, a green-yellow precipitate formed in the available free liquid. Two sulfide treated gels were prepared and dried at $135^{\circ} \mathrm{C}$ overnight. Each of the samples was tumbled with TCLP leach solution. Total exposure to the solution was 19 hours with the tumbling done for four hours at a faster rate than the TCLP procedure. Another treatment was also leached. An aliquot of the $81 \mathrm{H}$ product (heat treated at $600^{\circ} \mathrm{C}$ ) was water leached at ambient temperature for 24 hours, rinsed, and dried in the same manner as the other water leached samples. This water leached product was then submitted to the same modified TCLP procedure as the sulfide treated samples.

It is apparent that the treated material does not pass TCLP as shown in Table 5. The chromium value for the water leached $81 \mathrm{H}$ at $600^{\circ} \mathrm{C}$ barely makes it at $0.46 \mathrm{mg} / \mathrm{L}$. The limit is $0.6 \mathrm{mg} / \mathrm{L}$.

The cadmium fails all the acedic acid treatments but is apparently precipitated during the water leach at a higher $\mathrm{pH}$. If the chromium is heated in oxidizing conditions it will be present at least partially in the very soluble hexavalent state. It must be treated after most of the denitration has occurred where the leachate $\mathrm{pH}$ would be higher and the oxidizing potential lower. 
Table 5, Equivalent TCLP Leach Solution Analysis

Values in $\mathrm{mg} / \mathrm{L}$

\begin{tabular}{|c|c|c|c|c|}
\hline & $\begin{array}{c}\text { Sulfide Treated } \\
81 \mathrm{H} 170 \text { Acedic Acid } \\
\text { Leach 1 }\end{array}$ & $\begin{array}{c}\text { Sulfide Treated } \\
81 \mathrm{H} 170 \text { Acedic Acid } \\
\text { Leach 2 }\end{array}$ & $\begin{array}{c}\text { Water Washed } \\
81 \mathrm{H} 600 \text { Acedic Acid } \\
\text { Leach }\end{array}$ & 81H600 Water Leach \\
\hline $\mathrm{Cr}$ & 9.91 & 8.46 & 0.46 & 12.76 \\
\hline $\mathrm{Pb}$ & 4.28 & 3.61 & 0.77 & 0.23 \\
\hline $\mathrm{Cd}$ & 30.79 & 29.12 & 6.49 & 0.11 \\
\hline $\mathrm{Hg}$ & $>0.1$ & $>0.1$ & $>0.1$ & $>0.1$ \\
\hline
\end{tabular}

\section{Microscopic Examination}

The loaded gel particles are translucent when treated at low temperature. There is no visual indication of surface dried simulant. The yellow coloration appears to be uniform throughout each particle with some richer in color than others. When heated to over $130^{\circ} \mathrm{C}$ in open air, the loaded particles turn brown but are still translucent. The greater the waste loading, the darker the color. There is little perceptible change in the particle appearance until the $300^{\circ} \mathrm{C}$ treatment. At this point some sintering together of the smaller particles occurs and there are a small number of white opaque particles. The translucent brown particles have darkened. At higher temperatures, $400^{\circ} \mathrm{C}$ and $500^{\circ} \mathrm{C}$, there is little change in the darkening but there are more opaque particles and less sintering together. The changes from translucent to opaque indicate a chemical reaction within the dried simulant, between the simulant and the gel, or physical changes within the gel. All three could be possible.

Some of the heat treated gel product was submitted for SEM pictures and semi-quantitative analysis. Samples of the same gel products were also submitted for x-ray diffraction analyses. Scanning electron microscope pictures of $81 \mathrm{H}$ gel after being at temperatures of $110^{\circ} \mathrm{C}, 170^{\circ} \mathrm{C}$, and $600^{\circ} \mathrm{C}$ (Figures 8,9 , and 10 respectfully). It can be seen by examining the SEM pictures that the gel particles are mostly smooth with a possible thin coating of dried simulant. Small surface crystals of less than a micron can be seen at the high magnifications. A smaller number of larger crystals are scattered on the surface. At $600^{\circ} \mathrm{C}$ there is indication of surface changes, the nature of which cannot be fully ascertained until the XRD data is supplied. At the lower temperatures the dried simulant is mostly within the gel particles. The semi-quant. data indicate little change of surface composition with temperature except at $600^{\circ} \mathrm{C}$. The surface concentration of the sodium has greatly increased relative to the aluminum and silicon. 
Figure 8, $81 \mathrm{H}$ Product Particle from $110^{\circ} \mathrm{C}$ at Magnifications of $150 x$ and $5000 x$
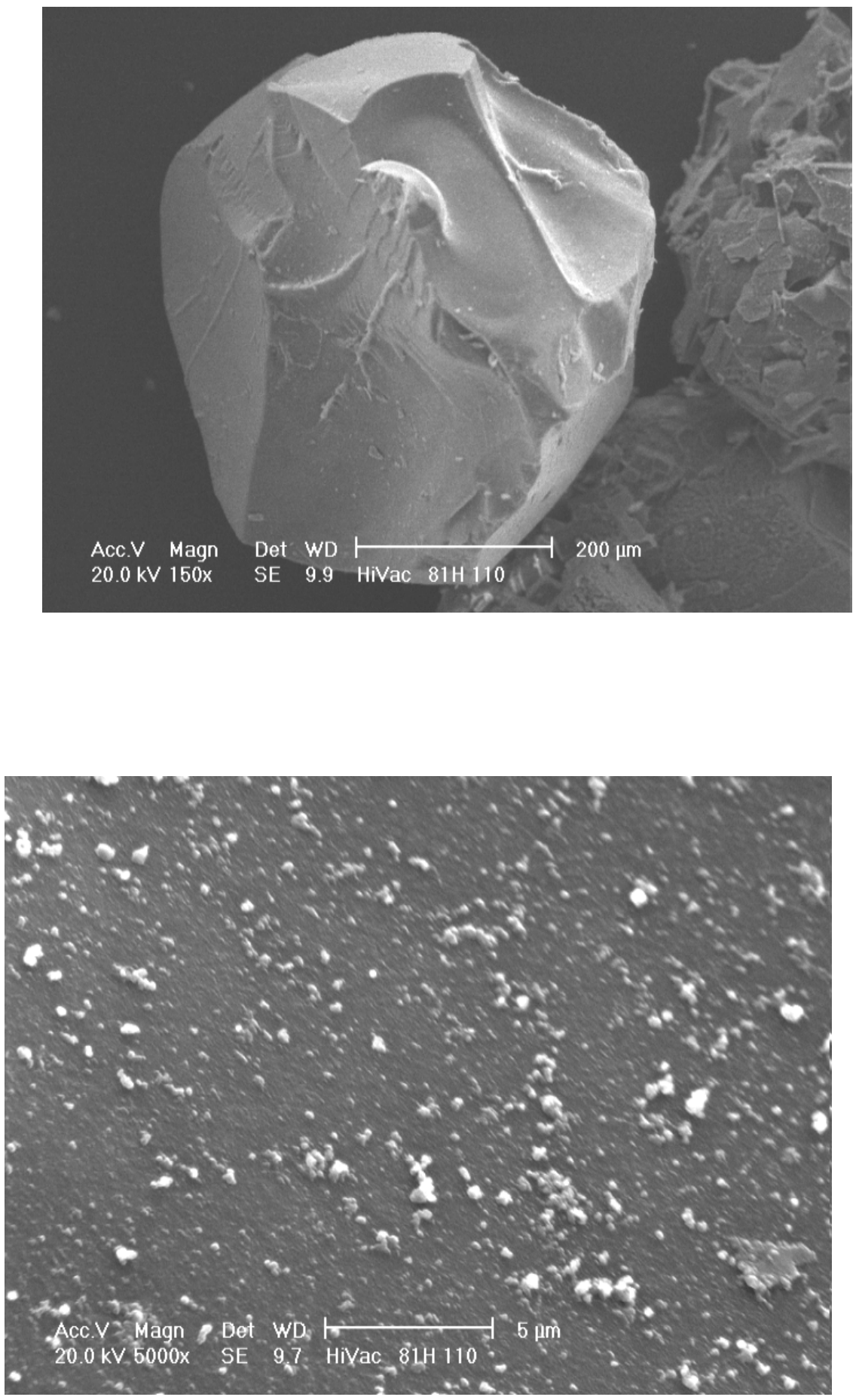
Figure 9, $81 \mathrm{H}$ Product Particle From $170^{\circ} \mathrm{C}$ at Magnifications of $250 x$ and $5000 x$
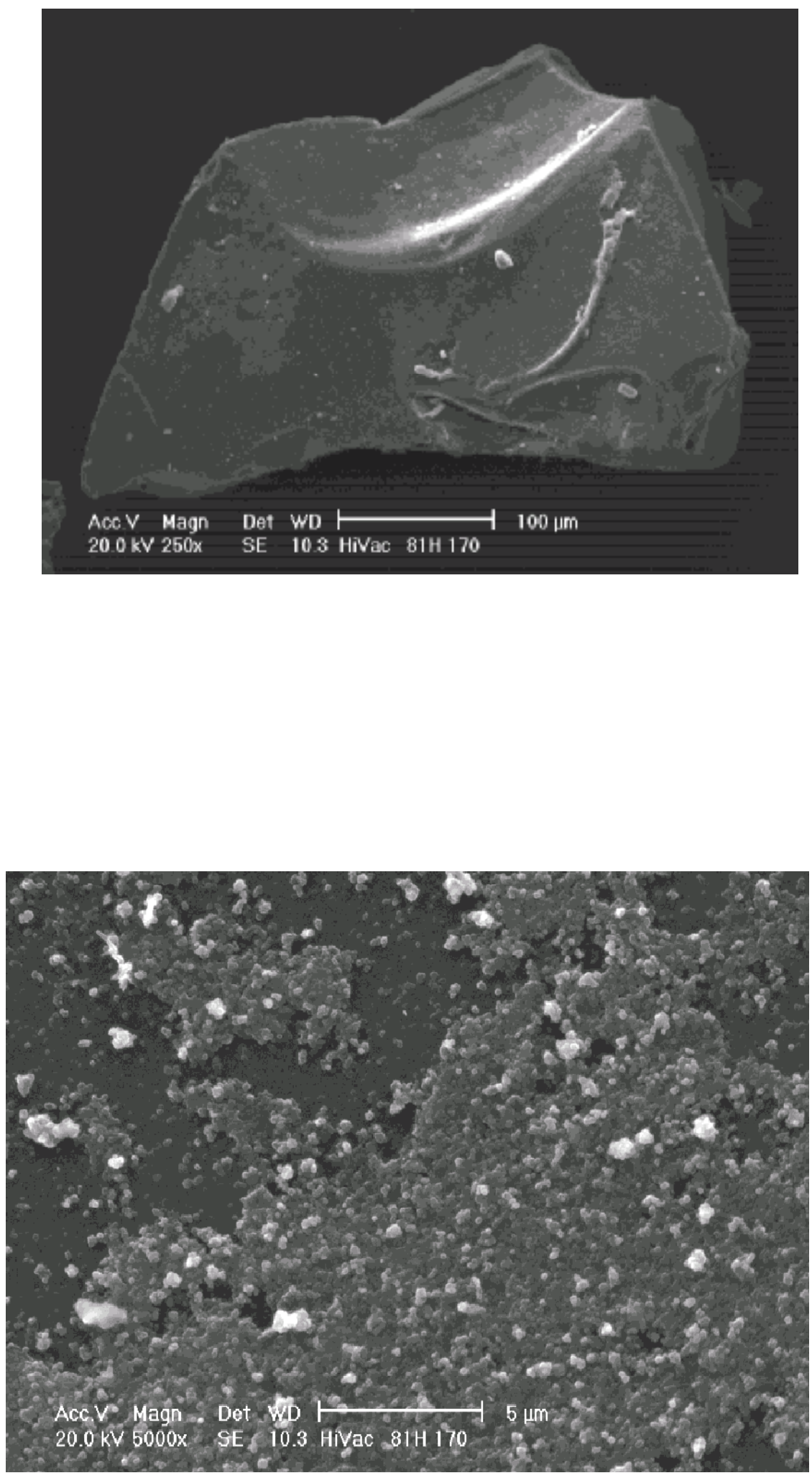
Figure 10, $81 \mathrm{H}$ Product Particle at a Temperature of $600^{\circ} \mathrm{C}$ at Magnifications of $150 x$ and $5000 x$
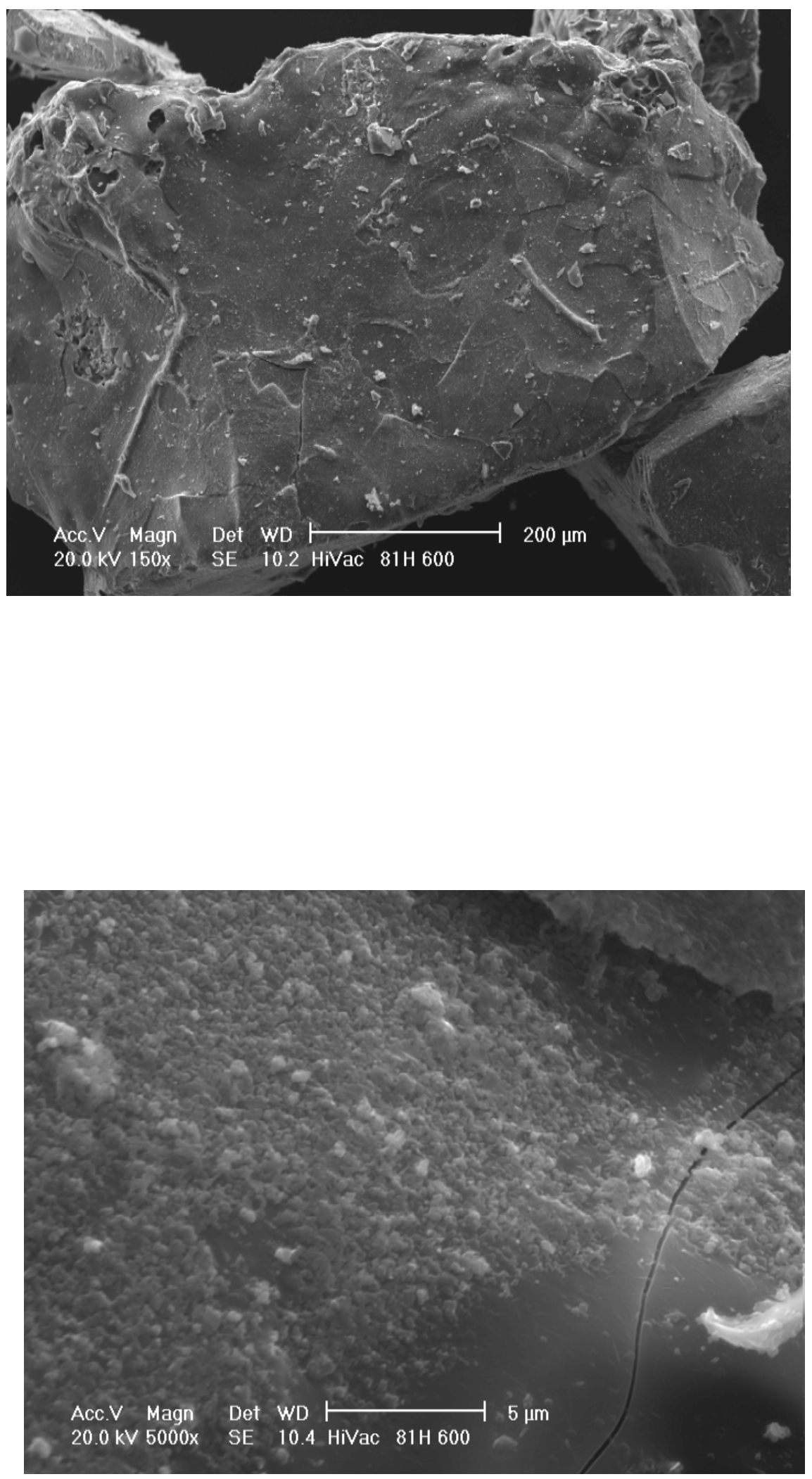


\section{Glass Formulation}

The loaded gel contains most components needed to make a glass. It is over rich in silica for the easily formed glasses. Several glass compositions were examined and one was selected that most closely matched the ratios in the loaded gel without too many or too much additives. A formulation nearly duplicating what is called T-glass ${ }^{5}$ was tried. Also tried was a modification of the Clemson glass formulation used on the concentrated SBW. For the formulations, two different waste loaded products were used, one was $70 \mathrm{wt} \%$ from a batch done earlier and the other was at $80 \mathrm{wt} \%$ from Run 4 . The overall formulation and test results are shown as Table 6. The glasses were made by mixing the gel product with the other glass components in a crucible and then melting crucible contents in a furnace at $1200^{\circ} \mathrm{C}$. They were allowed to stay at that temperature for a minimum of 6 hours.

Table 6, Concentrated SBW-Silica Gel Glass Formation

\begin{tabular}{|c|c|c|c|c|c|c|c|c|c|c|c|c|c|c|}
\hline \multirow[t]{2}{*}{ Glass } & \multirow{2}{*}{$\begin{array}{c}\text { Initial } \\
\text { Loading } \\
\text { Wt \% }\end{array}$} & \multirow{2}{*}{$\begin{array}{l}\text { Temp. of } \\
\text { Final Gel } \\
\text { Drying }{ }^{\circ} \mathrm{C}\end{array}$} & \multirow{2}{*}{$\begin{array}{c}\text { Final } \\
\text { SBW } \\
\text { Fraction } \\
\text { of gel } \\
\text { product } \\
\end{array}$} & \multirow{2}{*}{$\begin{array}{l}\text { Wt } \% \text { Gel } \\
\text { Product in } \\
\text { Glass Mix }\end{array}$} & \multicolumn{6}{|c|}{ Percent Added Glass Formers } & \multirow{2}{*}{$\begin{array}{l}\text { Glass } \\
\text { Density } \\
\text { Gm/cc }\end{array}$} & & \multirow{2}{*}{$\begin{array}{c}\text { PCT } \\
\text { Results } \\
\mu \mathrm{S} / \mathrm{cm} \\
\text { Cond. }\end{array}$} & \multirow{2}{*}{$\begin{array}{l}\text { Calculated } \\
\text { Volume } \\
\text { Reduction } \\
\text { for SBW \% }\end{array}$} \\
\hline & & & & & $\mathrm{B} 2 \mathrm{O} 3$ & $\mathrm{CaO}$ & $\mathrm{Fe} 2 \mathrm{O} 3$ & LiCO3 & $\mathrm{MgO}$ & TiO2 & & & & \\
\hline & & & & & & & & & & & & & & \\
\hline \multirow[t]{2}{*}{ G-70-CL } & 70.2 & 105 & 0.3739 & 78.4 & 10.5 & & \begin{tabular}{|l|}
4.71 \\
\end{tabular} & 4.94 & & 1.43 & 2.4378 & A & 273 & 81.9 \\
\hline & & & & & & & & & & & & $\mathrm{B}$ & 262 & \\
\hline \multirow[t]{2}{*}{ G-70-T } & 70.2 & 105 & 0.3739 & 74.4 & 2.96 & 17.9 & & & 4.68 & & 2.6062 & A & 295 & 85.5 \\
\hline & & & & & & & & & & & & $\mathrm{B}$ & 297 & \\
\hline \multirow[t]{2}{*}{ G-80-T } & 80.1 & 132 & 0.5152 & 77.5 & 2.7 & 15.7 & & & 4.11 & & 2.6152 & A & 460 & 89.8 \\
\hline & & & & & & & & & & & & $\mathrm{B}$ & 462 & \\
\hline \multirow{2}{*}{\begin{tabular}{|l} 
EA-1 \\
ARM-1 \\
\end{tabular}} & \multirow{2}{*}{\multicolumn{11}{|c|}{ For Comparison }} & & 3970 & \\
\hline & & & & & & & & & & & & & 150 & \\
\hline
\end{tabular}

All three glasses performed well in the PCT test and have good volume reduction relative to starting concentrated simulant. There was not enough glass product available to do any viscosity testing.

\section{Flowsheet}

A flowsheet was developed from the test data for drying the concentrated sodium bearing waste within and on silica gel (Figure 11). The waste loading is $81 \mathrm{wt} \%$ liquid simulant which becomes $51 \mathrm{wt} \%$ of the dried product. The flow rate used is $10 \mathrm{liter} / \mathrm{min}$ of concentrated SBW at a specific gravity of 1.32. The kinetics of the absorption of the SBW have not been studied in enough detail to size the mixer/drier. Enough residence time is required to assure that the gel becomes saturated. Experience has indicated that the residence time will exceed 30 minutes. 
Figure 11, Silica-SBW Flowsheet--10 Liter/Minute Conc. SBW

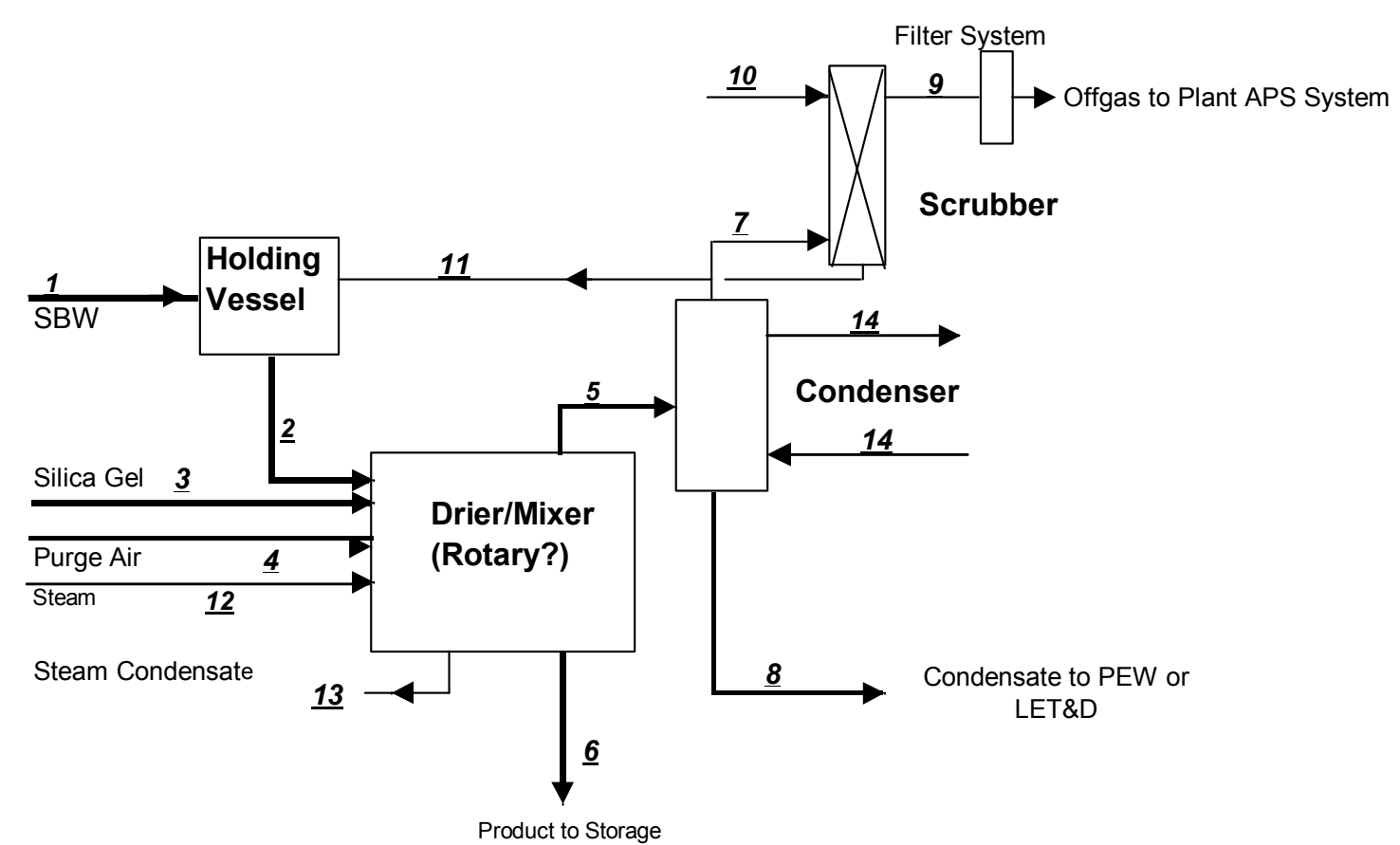

\begin{tabular}{|c|c|c|c|c|c|c|c|}
\hline Stream \# & 1 & 2 & 3 & 4 & 5 & 6 & 7 \\
\hline & Conc. SBW & \begin{tabular}{|c|} 
Conc. SBW + \\
Scrub \\
Recycle
\end{tabular} & Silica Gel & Purge Air & $\begin{array}{c}\text { Vapor @ } \\
130^{\circ} \mathrm{C}\end{array}$ & $\begin{array}{l}\text { Loaded Gel } \\
\text { Product }\end{array}$ & $\begin{array}{c}\text { Condenser } \\
\text { Offgas }\end{array}$ \\
\hline Flow Rate I/min. & 10 & 10.100 & 4.349 & 202.000 & 13694.898 & 6.767 & 202.404 \\
\hline Mass flow KG/min. & 13.18 & 13.312 & 3.123 & 0.199 & 10.249 & 6.185 & 0.201 \\
\hline Phase & Liq & Liq & Solid & Gas & Gas & Solid & Gas \\
\hline & & & \multicolumn{2}{|c|}{ Stream \# } & 12 & 13 & 14 \\
\hline & & & & & $\begin{array}{c}\text { Steam to } \\
\text { Drier }\end{array}$ & $\begin{array}{c}\text { Steam } \\
\text { Condensate }\end{array}$ & $\begin{array}{l}\text { Cooling } \\
\text { Water }\end{array}$ \\
\hline & & & Mass & $\mathrm{KG} / \mathrm{min}$. & 13.37 & 13.37 & 244.0 \\
\hline & & & Press. $\varsigma$ & $\mathrm{n} @ 140^{\circ} \mathrm{C}$ & $\begin{array}{l}349 \mathrm{KPa} \\
\text { (52psia) } \\
\end{array}$ & & \\
\hline
\end{tabular}




\section{CONCLUSIONS AND RECOMENDATIONS}

From the experimental data and literature studied, the silica gel drying process could have a practical use for the treatment, or as a step in the treatment, of several INEEL liquid wastes.

Desirable features found are the ability to:

1. Dry the liquid easily,

2. Remove the acidity without producing a syrupy liquid,

3. Remove a good fraction of the nitrate,

4. Produce a dry flowable and storable solid.

All of the above are accomplished at a reasonable temperature with some volume reduction even with a very concentrated solution.

The product can be processed into an excellent glass with a good volume reduction. This process should definitely be considered as a pretreatment to a glass melting process or any process that will produce the final waste form. It eliminates the complications to design and operation caused by acid gases and water at high temperatures. Alternatively, the silica gel process could solidify the liquid wastes for transport to another site for final processing.

Several questions have surfaced while conducting this study and need to be answered before design work:

1. The kinetics of the sorption and evaporation processes are needed so that a proper mixer drier can be designed.

2. Long range stability of the product is not known. At what overall waste loadings and humidity will the products maintain their flowability?

3. Are there better gel materials or combination gels that can perform better and produce a less leachable product? The few trials made with other materials were very disappointing. Additional material studies are needed to optimize the process. 


\section{REFERENCES}

1. Nardova, A. K. and Tumanova, O. S. , "Examination of Mechanism of Saturation of Silica Gel with Metals at High Temperatures", Spectrum 1996 Proceedings.

2. Cicero-Herman, C.A. et al, "Silica Gel Treatment For Stabilization of Radioactive Materials", Westinghouse Savannah River Company Report WSRC-TR-97-0095, March 1997.

3. Maatman R. W. et al, "The Exchange of Twenty Metal Ions with the Weakly Acidic Silanol Group of Silica Gel," J. of Phys. Chem. 68 No 4 pp757 April 1964.

4. Meites L. et al, "Exchange of $\mathrm{Na}+$ for the Silanolic Protons of Silica."J. inorg. nucl. 33, Oct 1971 pp.1293-1299.

5. Kirk-Othmer Encyclopedia of Chemical Technology, Third Edition, Volume 11, 1980, pp 826-829. 